\title{
Youngsters Attitude towards Mobile Marketing
}

\author{
K.R Shabhu, Aathira Nandakumar and Aswathi Nandakumar
}

\begin{abstract}
Marketing with the help of mobile phones will help the brand managers to communicate with the customers through SMS, MMS and other available services. Considering the fact that today's youngsters are tomorrow's consumers, there is a need to prepare youngsters to consider different consumption patterns. This is done with the aim to empower young consumers to access the market with clearer ideas and to develop their capacity to select among existing products and services. Producers on the other hand have powerful resources and therefore the consumers or youngsters cannot adopt defensive strategies. The competition faced by these producers are high that they have to adopt new and improved way of marketing the products and they have to ensure that they reach the core customers while marketing their product.
\end{abstract}

Keywords--- Mobile, Marketing, Youngsters

\section{INTRODUCTION}

$\mathrm{I}_{\mathrm{b}}^{\mathrm{N}}$ NFORMATION technology has affected everything in the business. Due to the presence of immense competition it has become necessary that effective marketing techniques are to be adopted by the organisation. Thus, it has been advised that for the producers to stay competitive in the market they will have to use the technological advancements available in the market. These technological advancements have led to the invention of mobile phones and this has been a mile stone in communication media. This advancement has resulted in easier communication between people from different countries, cultural backgrounds and profile communicate with each other more easily. It has become much easier to access internet with the help of mobile phones even in the absence of computers.

Mobile phones have influenced the youngsters with the coming of mobile internet. With this advancement people can easily access the world out of their reach with a press on a button. The customers are now more aware about the changes in the market and they are considered an integral part of any business as now the market is expanding beyond market. This trends has lead to the introduction of mobile marketing as mobile is considered as an inevitable part of life of youngsters.

Mobile phones have influenced the way the market works and thinks. It is used as a tool for targeting, interacting and establishing relationships with the customers. Mobiles help in easy communication between the 2 ends. Mobile phones also

K.R. Shabhu, Assistant Professor, Amrita School of Arts and Sciences, Kochi.E-mail:shabhukr@gmail.com

Aathira Nandakumar, Amrita School of Arts and Sciences, Kochi. E-mail:aathiran.94@gmail.com

Aswathi Nandakumar, Amrita Vishwa Vidhyapeetham, Coimbatore. E-mail:aswathyn.94@gmail.com

DOI: 10.9756/BIJIEMS.7467 have a descent storage capacity that helps the youngsters store music and other video content in their phone.

This adoption of mobile phones by people have created a need for understanding the trends of mobile marketing and the factors that affect the marketing behavior.

With the evolution of e-commerce a new marketing channel has emerged known as mobile marketing. Mobile marketing has resulted in further development of media industry as a whole. Other names for mobile marketing are wireless marketing, mobile advertising and wireless advertising.

\section{STATEMENT OF THE PROBLEM}

The paper aims to find out how mobile marketing has influenced the purchasing pattern among youngsters. So the statement of this project would be "Impact of Mobile Marketing On Youngsters in Ernakulam district".

\section{SCOPE OF THE STUDY}

Consumers of today are knowledgeable and they know what they want. They never compromise on the quality of products used by them. They are well aware about the brands and competition between these brands. They ensure that they are never exploited by these competitors.

The paper intends to study the effectiveness of Mobile Marketing among youngsters. The target audience for this study is youngsters i.e. the people in the age group of 18-35.

\section{OBJECTIVES OF THE STUDY}

The primary objective of the study is to find out the impact of Mobile Marketing on youngsters. The other objectives are :

1. To evaluate whether the youth has accepted Mobile Marketing.

2. To understand whether the industry has adopted Mobile Marketing as an effective marketing strategy from the point of view of customers.

\section{Research Methodology}

The data used for the study has been collected from both primary and secondary sources. Primary data has been collected through questionnaires containing 20 questions from respondents within Ernakulam district based on convenient sampling. The secondary data has been collected from various research journals, books, and magazines.

\section{SAMPLE UNIT}

Sample unit is expected to be the way the universe behaves. The data collected in this research are of primary and secondary nature. 
In order to collect primary data from 100 respondents, convenient sampling was adopted. The analysis of the same has been done using percentage analysis.

\section{LIMITATIONS OF THE STUDY}

- The study is conducted only in Ernakulam district.

- The study is conducted only for a particular period of time.

- The sample unit studied is only 100 due to time constraints.

\section{ANALYSIS}

It has been inferred from the study that it improves the purchasing power.

- $70 \%$ consumers feel that their purchasing power has improved and the remaining 30\% feels that mobile marketing does not influence their purchasing power.

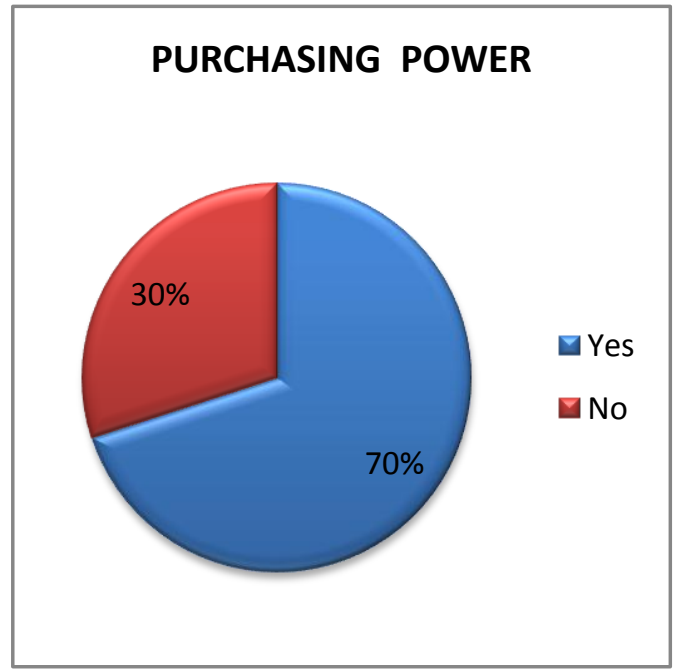

From the study we could analyze that

- There were mixed feedback about the comfort level while receiving mobile ads.(60-40\%)

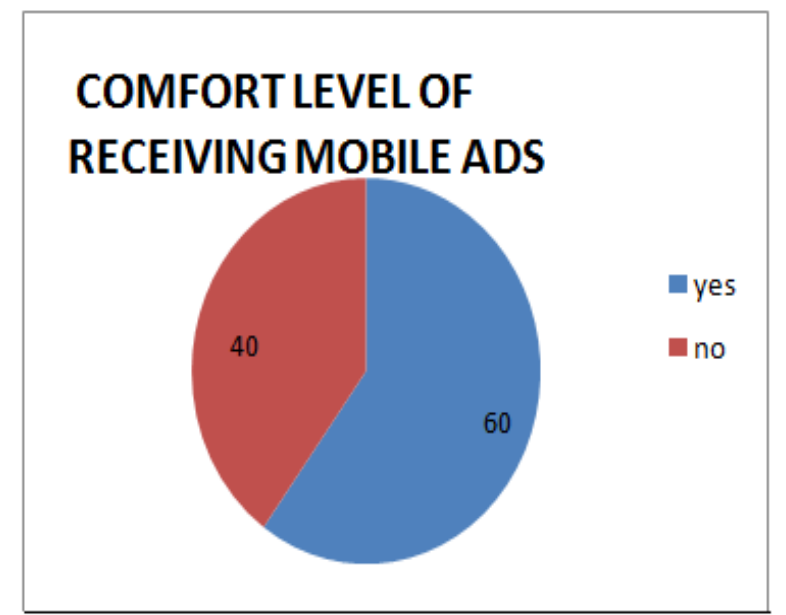

From the study it has been found that majority of the respondents find Mobile Marketing to be time saving.
- $74 \%$ finds it to be time saving while $26 \%$ considers it to be time consuming.

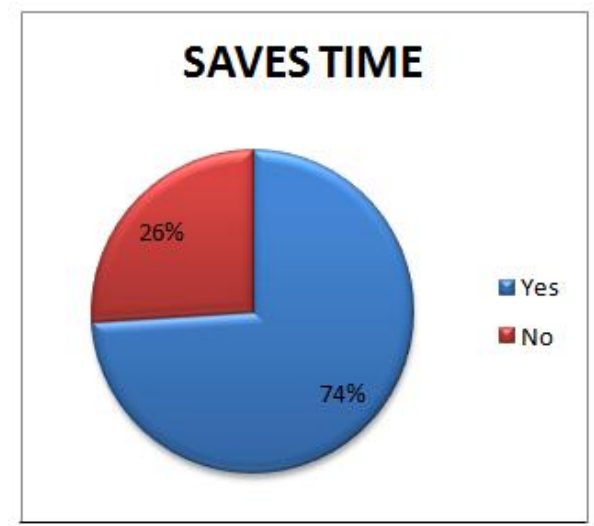

The study conducted has revealed

- Mobile ads have influenced the youngsters to purchase products. $(75 \%)$

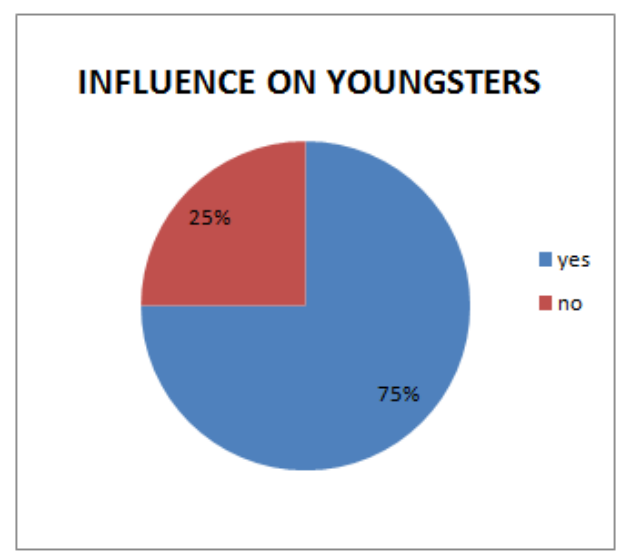

The study infers that

- Consumers do not find Mobile Advertising as a trust worthy source of information.(70\%)

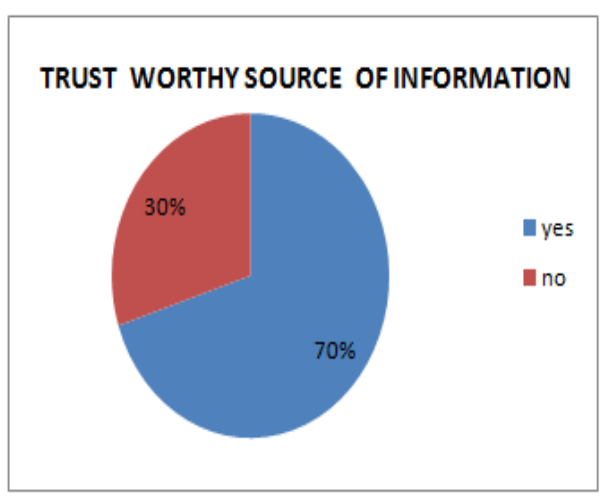

\section{OTHER FINDINGS}

- Most of them included in the survey are android phone users.(95\%)

- These advertisements are accessible.(98\%)

- Even those Consumers who are not active buyers, consider it as a source of information

- Most of these consumers receive ads frequently.(90\%) 
- Almost everyone has come across false claims and rewards. $(97 \%)$

- Some of them consider it as an opportunity to know about the products while others consider it as a hindrance while at work. (63-37\%)

- Most of them do not respond to tele callers(94\%).

- Consumers being more aware about the market, has always taken that extra effort to see that they are well informed about the product.

- Tele callers are not entertained by most of them.

- Advertisements are considered as the best source of information about the product.

\section{SugGestions}

- Mobile Marketing has a positive impact and this should be exploited by both the producers and consumers for efficient results.

- Advertisements in no way should be against the values in our society.

- It would be appreciable if they take up necessary actions to restrict the messages stating the claims and awards.

\section{CONCLUSION}

India-being a developing country has no proper access to technology and as a result there are still remote areas which have no proper basic amenities. On the other hand in urban areas there are people with more than 1 mobile phone. As a result, mobile marketing can be useful for those products that are used by semi-urban and urban areas. There is also no scope for mobile marketing in rural areas where the people are illiterate and people do not actually depend on electronic gadgets to make purchase decisions. There is a need for the producers to ensure that the marketing technique used is modern and at the same time it should cover the needs of consumers.

Consumers are the king of the market and so the producers are expected to run after the consumers for selling their products. It is essential to see that the information that is conveyed to the consumers are worth it. Consumer should not be exploited by the producers. The competition faced by these producers are high that they have to adopt new and improved way of marketing the products and they have to ensure that they reach the core customers while marketing their products. Consumers of today are expecting the best from their sellers, they always compare their products based on different criteria. They also receive information about each product at their fingertip. So it's essential to practice aggressive marketing without disturbing the privacy of the customers.

\section{REFERENCES}

[1] D.T. Geetika and P. Gupta, "A Study of Indian Consumers' Perception on Telemarketing", International Journal of e-Education, e-Business, eManagement and e-Learning, Vol.2, No.2, Pp.97-102, 2012

[2] R. Roushan, M. Mehta and A. Chandani, "Study of Mobile Marketing Communication in India", Indian Journal of Science and Technology, Vol. 8, No.S6, PP.125-131, 2015.
[3] M.E. Goldberg, G.J. Gorn, L.A. Peracchio and G. Bamossy, "Understanding materialism among youth", Journal of Consumer Psychology, Vol.13 No.3, Pp.278-88, 2003.

[4] M. Hanley and M. Becker, "Cell Phone Usage and Advertising Acceptance Among College Students", International Journal of Mobile Marketing, Vol. 3, Pp. 67-81, 2008

[5] Y. Chou, C.H. Ho and Y.W. Chui, "Customer Value Toward Short Message Service: An Empirical Investigation", The International Journal of Organizational Innovation, Vol.2, Pp.356-367, 2009.

[6] J. Choi, H. Seol, S. Lee, H. Cho and Y. Park, "Customer Satisfaction Factors of Mobile Commerce in Korea", Internet Research, Vol.18, Pp. 313-335, 2008.

[7] David G. Taylor, Troy A. Voelker and I. Pentina, "Mobile Application Adoption by Young Adults:A Social Network Perspective", International Journal of Mobile Marketing, Vol.6, No.2, Pp.60-70, 2011.

[8] N. Mallat, M. Rossi, V.K. Tuunainen and A. Öörni, "The Impact of Use Context on Mobile Services Acceptance:The Case of Mobile Ticketing", Information \& Management, Vol.46, Pp.190-195, 2009.

[9] B. Abbass Al-alak and I. Akram Alnawas, "Mobile Marketing: Examining the Impact of Trust, Privacy Concern and Consumers' Attitudes on Intention to Purchase", International Journal of Business and Management, Vol.3, Pp. 28-41, 2010. 